\title{
MOIST TEMPERATE FOREST BUTTERFLIES OF WESTERN BHUTAN
}

Arun P. Singh

ISSN 0974-7907 (Online) ISSN 0974-7893 (Print)
Forest Entomology Division, Forest Research Institute, P.O. New Forest, Dehradun, Uttarakhand 248006, India singhap@icfre.org, ranoteaps@gmail.com

\section{OPEN ACCESS}

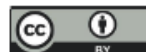

Abstract: Random surveys were carried out in moist temperate forests $(1,860-3,116 \mathrm{~m})$ around Bunakha Village and Dochula Pass, near Thimphu in western Bhutan, recording 65 species of butterflies. Of these, 11 species, viz., Straightwing Blue Orthomiella pontis pontis Elwes, Slate Royal Maneca bhotea bhotea Moore, Dull Green Hairstreak Esakiozephyrus icana Moore, Yellow Woodbrown Lethe nicetas Hewitson, Small Silverfork Zophoessa jalaurida elwesi Moore, Scarce Labyrinth, Neope pulahina (Evans), Chumbi Wall Chonala masoni Elwes, Pale Hockeystick Sailer Neptis manasa manasa Moore and White Commodore Parasarpa dudu dudu Westwood, are restricted to the eastern Himalaya, northeastern India and Myanmar. Two other species, Tawny Mime Chiasa agestor agestor (Gray) and Himalayan Spotted Flat Celaenorrhinus munda Moore have been only rarely recorded from Bhutan and a few individuals of the rare Bhutan Glory Bhutanitis lidderdalei Atkinson were also recorded near Bunakha.

Keywords: Biodiversity hotspot, Bhutanitis lidderdalei, Bunakha, Dochula Pass, eastern Himalaya, Ha Chu River, Lepidoptera, Wang Chu River.

Bhutan, part of the Himalayan biodiversity hotspot, is home to an estimated 750 species of butterflies (Singh $\&$ Pandey 2004). Very recently, efforts have been made to document the butterfly diversity of this region (Poel \& Wangchuk 2007; Singh 2012; Wangdi et al. 2012, 2013; Wangdi \& Sherub 2012a,b; Singh \& Chib 2014; Tshering 2015). However, information generated on butterflies of this region is far from complete. Random surveys were carried out in 'moist temperate forests' at elevations ranging from $1860-3116 \mathrm{~m}$ in the western part of Bhutan around Dochula Pass on the way to Punakha from Thimphu and also around Chukha-Bunakha villages along the Wang Chu River catchment, which lie enroute from Thimphu to Phuntsholing during late-spring, premonsoon, monsoon, post-monsoon seasons during 2009-2013 (Image 1).

\section{MATERIALS AND Methods \\ Study sites and vegetation}

The study was carried out in typical forest types at different altitudes. The first site of the study was the forest around Dochula Pass (Image 1,site-I; 3116m) which is located on the way to Punakha town from Thimphu which is a moist temperate coniferous forest, dominated by Tsuga dumosa mixed with Rhododendron spp. and many broad leaved species such as Acer sp., Castonopis sp., etc. and this pass descends down to the Royal Botanical Garden at Lampere. The landmarks around the Dochula pass include 108 Druk Wangyal Khang Zhang Chortens or Stupas. The second site was the forest habitat from Chukha to Bunakha village until Tanalum check post $\left(27^{\circ} 04^{\prime} 30.1^{\prime \prime}-27^{0} 13^{\prime} 55.9^{\prime \prime} \mathrm{N} \& 89^{\circ} 29^{\prime} 11.5^{\prime \prime}-\right.$ $\left.89^{\circ} 33^{\prime} 58.1^{\prime \prime} \mathrm{E}\right)$. The vegetation in and around Bunakha

DOI: http://dx.doi.org/10.11609/jott.2297.8.3.8596-8601 | ZooBank: urn:Isid:zoobank.org:pub:AA79CEF0-17C0-45FB-A6A9-1D6152D472C6

Editor: George Mathew, KFRI, Peechi, India. Date of publication: 26 March 2016 (online \& print)

Manuscript details: Ms \# 2297 | Received 14 September 2015 | Final received 08 February 2016 | Finally accepted 12 March 2016

Citation: Singh, A.P. (2016). Moist temperate forest butterflies of western Bhutan. Journal of Threatened Taxa 8(3): 8596-8601; http://dx.doi.org/10.11609/ jott.2297.8.3.8596-8601

Copyright: (c) Singh et al. 2016. Creative Commons Attribution 4.0 International License. JoTT allows unrestricted use of this article in any medium, reproduction and distribution by providing adequate credit to the authors and the source of publication.

Funding: Indian Council of Forestry Research \& Education (ICFRE), Dehradun.

Conflict of Interest: The author declares no competing interests

Acknowledgments: I am thankful to Monsoon Jyoti Gogoi and Motoki Saito for their help in identification of butterflies. 


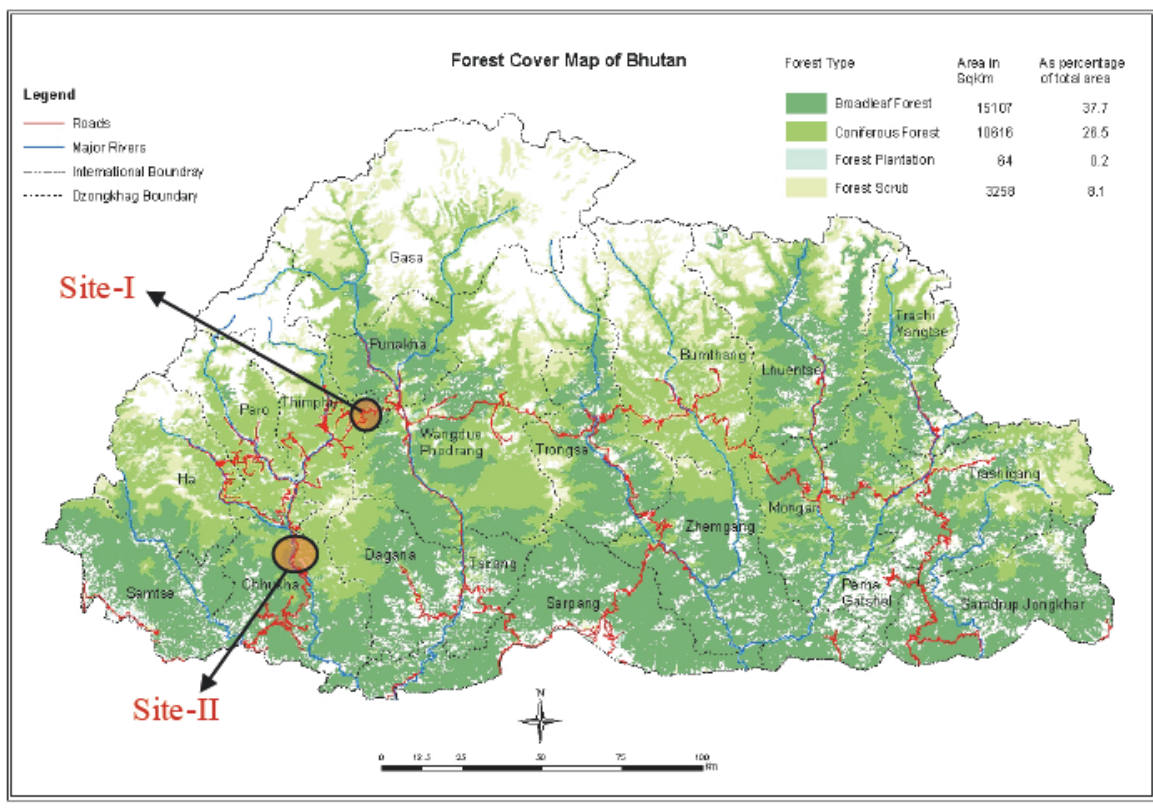

Image 1. Location of moist temperate forest study sites: site I-Dochula Pass \& site II-Bunkha Village in western Bhutan.

(Source: http://www.comap.ca/ kmland/display.php?ID=315)
(1,860-2,580 m; Image 1 , site-II) up to higher elevations is dominated by Populus gamblei, Acer compbellii, Alnus nepalensis, Pinus wallichiana community. The vegetation varies from broad-leaved to evergreen-oak pine forests. The common tree species recorded in this area are Alnus nepalensis, Acer campbelli, Carpinus viminea, Juglans regia, Quercus glauca, Rhododendron arboreum, Symplocos ramisissima, Pinus wallichiana and Picea spinulosa. Other important tree species are Benthamidia capitatum, Carpinus faginea, Celtis tetrandra, Coriaria nepalensis, Cornus capitata, Corylus ferox, Dysoxylum binectariferum, Lindera assamica, Lyonia ovalifolia, Persea duthei, Populus gamblei, Salix obscura, Toricellia tiliifolia, Viburnum mullaha and Zanthoxylum sp.

\section{Sampling}

Observations were recorded during day time (10:3015:00 hr) around Dochula Pass (site-I) by trekking down to the Royal Botanical Garden at Lampere on 08 July 2009 (monsoon season). Surveys were also carried out in and around Chukha-Tsimasham-Bunakha Village (SiteII) by trekking along the highway up to Talalium check post before Chapcha while moving towards Thimphu. Surveys in site-II were carried out (10:00-15:00 hr) on 12-14 and 16 May 2009 (pre-monsoon season when day time temperatures varied between $17.8-20{ }^{\circ} \mathrm{C}$ and relative humidity varied between 71-78\%), 09 July 2009 (monsoon season), 27-28 April 2011 (late spring season) and 21-22 September 2012 (post monsoon season). All the butterflies encountered while walking along the highway and a trail going down to the river Wang Chu were noted and photographed for identification.

\section{Identification of butterflies}

Identification of butterflies was done with the help of field guides (Evans 1932; Wynter-Blyth 1957; Haribal 1992; Smith 1989, 2006; Kehimkar 2008) as well as web resources (http://www.ifoundbutterflies.org/ and http://flutters.org/). Photographs were compared with the specimens at National Forest Insect Reference Collection at Forest Research Institute, Dehradun, India.

\section{RESULTS AND DISCUSSION}

A total of 65 species were recorded during these short surveys from the two sites that are listed in the Appendix. Butterflies recorded in this study belonged to five families. Maximum number of species were from Nymphalidae, followed by Lycaenidae, Pieridae, Papilionidae and Hesperiidae. Most of the collections were from Bunakha except for nine species (Golden Sapphire Heliophorus brahma, Green Sapphire Heliophrous androcles, Dull Green Hairstreak Esakiozephyrus icana, Slate Royal Maneca bhotea, Yellow Woodbrown Lethe nicetas, Chumbi Wall Chonala masoni, Scarce Labyrinth Neope pulahina, Small Silverfork Zophoessa jalaurida elwesi and Blue Pansy Junonia orithiya) which were recorded from Dochula only. The reason for the few records being overcast and cold weather conditions prevailing at Dochula Pass on 
the day of survey. Besides, a few individuals $(3+)$ of the rare Bhutan Glory, Bhutanitis lidderdalei Atkinson (listed in CITES-Appendix II) were also recorded at Tsimasham near Bunakha on 22 September 2012. Of the various species recorded in this study, the following were of interest being mainly new records for Bhutan.

1. Tawny Mime Chiasa agestor agestor (Gray) (Image 2).

One individual was photographed perched on Coriaria nepalensis shrub in a forest dominated by Quercus glauca trees along the highway near Bunakha on 14 May 2009. This sub-species was reported as 'not rare' from Sikkim to Dawnas (Myanmar) by Evans (1932). Wynter-blyth (1957) reported it from clearings in oak forests during early April in the eastern Himalaya Smith (1989) reported it from central to western Nepal. Recorded from Linza in Tholung Valley in light wooded country in Sikkim by Haribal (1992). The species was reported by Kehimkar from Himalaya and hills of northeastern India (2008) between 1,200-2,590 m. No earlier records from Bhutan.

\section{Straightwing Blue Orthomiella pontis pontis}

\section{Elwes (Image 3).}

A few individuals were recorded on wet mud on the highway near Bunakha Village $(n=3)$ and in Bunakha Village $(n=4)$ on 13 May 2009 and also on 28 April 2011. Evans (1932) reported this species from Sikkim, northeastern India and Myanmar including Arunachal Pradesh. It prefers dense jungle between 900-1800 m from March to June and is 'very local' from Sikkim to Assam and northern Myanmar as reported by WynterBlyth (1957). Smith (1989) recorded it from Nepal between 1,950-2,040 m during April. Not reported earlier from Bhutan.

\section{Slate Royal Maneca bhotea bhotea Moore (Image} 4).

One individual was reported nectaring on flowers on 8 July 2009, about $1 \mathrm{~km}$ before Dochula from Thimphu along the side of the road. Tytler (1925) recorded it during June-July from Kabru Peak and Suroifui in Manipur between 2,400-2,700 $\mathrm{m}$ and also Sikkim. Evans (1932) reports it to be a rare species from Sikkim to Assam. Wynter-blyth (1957) found it to be 'rare' from Darjeeling to Assam during May-July, in October in Naga Hills and during January in Khasi Hills. The species is 'very rare' in central Nepal between 2,484-2,700 m during MayJune and is 'rare' in Sikkim and Assam according to Smith (1989). Khanal et al. (2013) collected four specimens from central Nepal between 2,484-2,730 m. A male collected by Ollenbach from Darjeeling, West Bengal on 13 June 1909 is kept in National Insect Collection at Forest Research Institute, Dehradun. Not reported earlier from Bhutan.

\section{Dull Green Hairstreak Esakiozephyrus icana} Moore (Image 5).

Two individuals of this species were recorded feeding on the wet ground along the road below Dochula Pass in Bhutan. This is probably the eastern most record of this species in the Himalaya. It occurs in western and central Nepal from 1,850-2,636 m from June to August as reported by Smith (1989). Evans (1932) reported it to be 'rare' from Kullu to Kumaon. Also occurs in western China (Smith 1989). Its range in the Himalaya extends from Himachal Pradesh to Uttarakhand as per Kehimkar (2008). Not reported earlier from Bhutan.

\section{Yellow Woodbrown Lethe nicetas Hewitson} (Image 6).

One individual was recorded on 08 July 2009 below Dochula Pass along the road side vegetation. Both Evans (1932) and Wynter-blyth (1957) found this species to be 'not rare' from Kullu to Arunachal Pradesh and Manipur. Poel \& Wangchuk (2007) found it to be 'fairly common' between 1,700-2,600 m along the forest trails, occasionally visiting sweaty shoes in Bhutan. Haribal (1992) found it 'rare' in Sikkim. Recorded as uncommon from 1860-2800 m during July and November in Nepal by Smith (1989). Its range extends from Himachal Pradesh to Arunachal Pradesh, northeastern India, Nepal, Bhutan and Myanmar as per Kehimkar (2008).

6. Small Silverfork Zophoessa jalaurida elwesi Moore (Image 7).

One individual was recorded on herbaceous vegetation along the road below Dochula Pass on 08 July 2009. Haribal (1992) found it in Sikkim between 2,000$3,000 \mathrm{~m}$ on slopes covered with bamboo whereas it is 'not rare' in Sikkim as per Evans (1932). Also occurs from east to central Nepal as 'local' but 'not rare' between 2700-3840 m from July to September as recorded by Smith (1989). A female collected by Ollenbach on 11 September 1915 at Tendong, Sikkim is kept in the National Insect Collection at Forest Research Institute, Dehradun. Sub-species elwesi not reported earlier from Bhutan.

7. Scarce Labyrinth Neope pulahina (Evans) (Image 8).

One individual was recorded feeding on animal refuse along the road below Dochula Pass on 8 July 2009. A rare species found from Sikkim to Arunachal Pradesh, Manipur, Nepal, Bhutan and Myanmar between 1,2002,800 m from May-July as per Evans (1932), Smith (1989), Haribal (1992), and Kehimar (2008). A female collected by Ollenbach on 27 June 1904 from Darjeeling, 


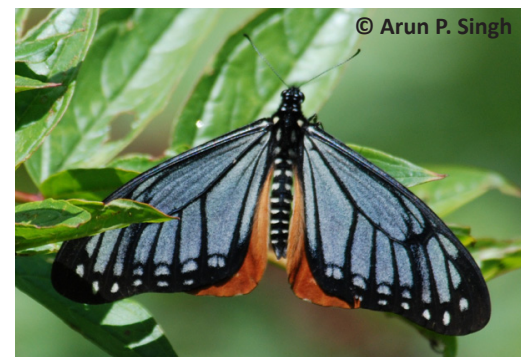

Image 2. Tawny Mime Chiasa agestor agestor (Gray)

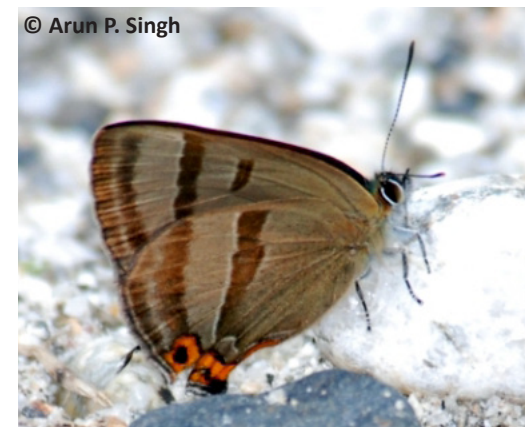

Image 5. Dull Green Hairstreak Esakiozephyrus icana Moore

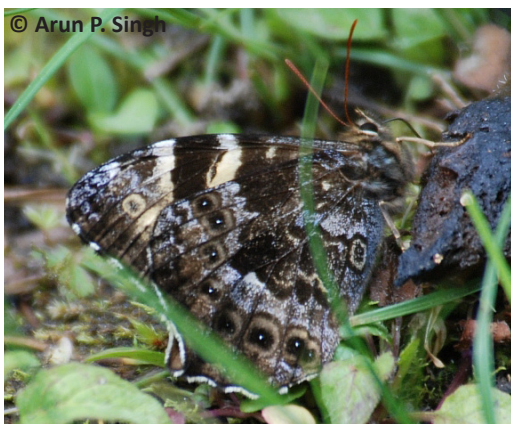

Image 8. Scarce Labyrinth Neope pulahina (Evans)

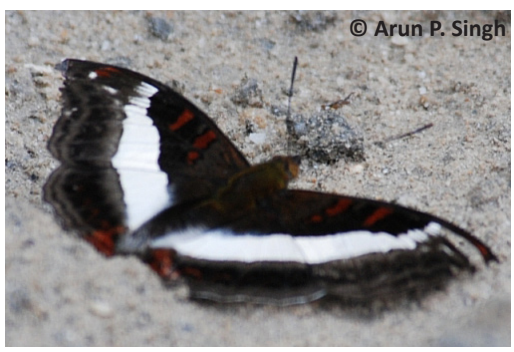

Image 11. White Commodore Parasarpa dudu dudu Westwood

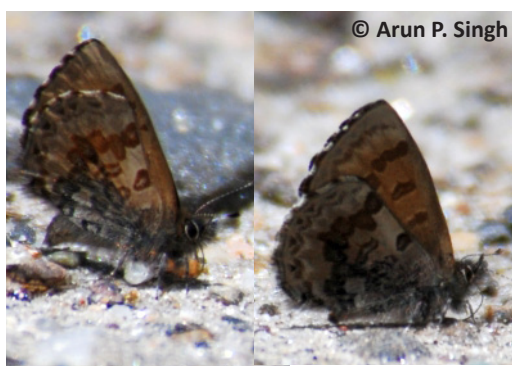

Image 3. Straightwing Blue

Orthomiella pontis pontis Elwes

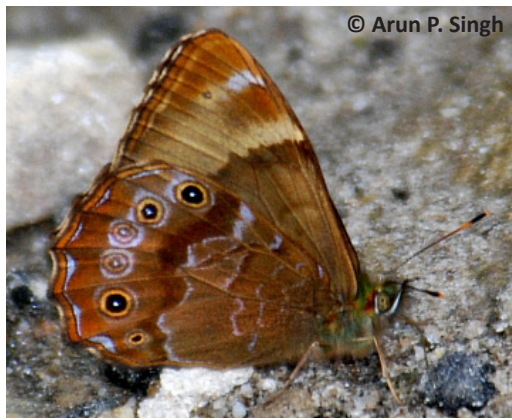

Image 6. Yellow Woodbrown Lethe nicetas Hewitson

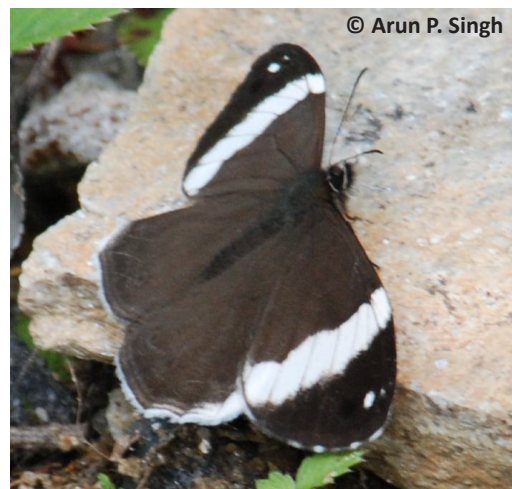

Image 9. Chumbi Wall Chonala masoni Elwes

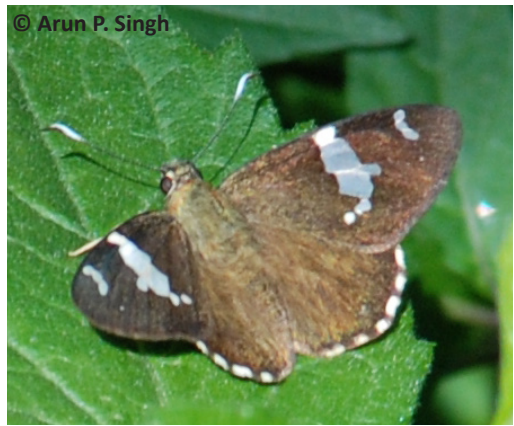

Image 12. Himalayan Spotted Flat Celaenorrhinus munda Moore

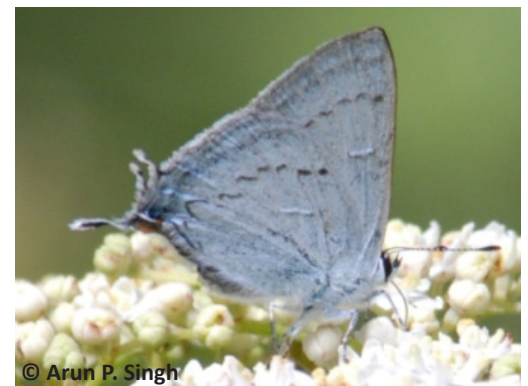

Image 4. Slate Royal Maneca bhotea bhotea Moore

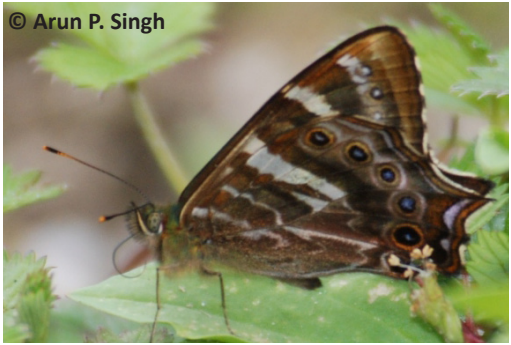

Image 7. Small Silverfork Zophoessa jalaurida elwesi Moore

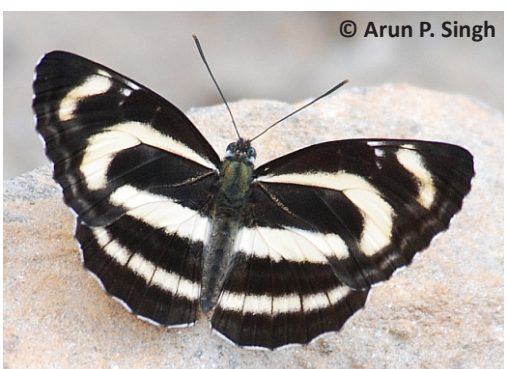

Image 10. Pale Hockeystick Sailer Neptis manasa manasa Moore 
West Bengal is kept in the National Insect Collection at Forest Research Institute, Dehradun. Not reported earlier from Bhutan.

\section{Chumbi Wall Chonala masoni Elwes (Image 9).}

One individual was noted sucking salt from a rock along the road below Dochula Pass on 8 July 2009. Evans (1932) reported it to be 'not rare' from Sikkim to Bhutan. Haribal (1992) reported it from Upper Teesta Valley in Sikkim. Also recorded in August from Mayodia Pass ( 2,200m) in Dibang Valley District, Arunachal Pradesh by the author (unpublished). Not reported earlier from Bhutan.

9. Pale Hockeystick Sailer Neptis manasa manasa Moore (Image 10).

One individual was noted on the road side rocks sucking salts on wet sand along the bridge below Chaukha. Evans (1932) reports it to be 'very rare' from Sikkim to Shan states in Myanmar while Smith (1989) reported it from Kathmandu Valley in central Nepal where it was very rare during May-June between 1,8002,372 m. Also recorded in Mishmi Hills in lower Dibang Valley, Aunachal Pradesh in June by Gogoi (2012). Khanal et al. (2013) collected five specimens from central Nepal between 1,520-2,151 m.

10. White Commodore Parasarpa dudu dudu

\section{Westwood (Image 11)}

One individual was noted drinking salt from wet sand from eroded rocks along the river bridge $(1800 \mathrm{~m})$ near Chaukha. Evans (1932) reports it as a 'rare' species occurring from Sikkim to Shan States in Myanmar. Wynter-Blyth (1957) and Smith (1989) reported it from central Nepal during April-May and July-October up to Sikkim, hills of northeastern India up to southern Shan States, Formosa and Hongkong and in Sikkim between 1200-1500 m. Haribal (1992) recorded it flying around tree tops and ridges in Sikkim. Also occurs in Bhutan in forested areas between 1,400-2,650 $\mathrm{m}$ as reported by Kehimkar (2008) and from Trashiyangtse Valley, eastern Bhutan by Wangdi et al. (2013) and between 1,400 $2,500 \mathrm{~m}$ in Bhutan by Poel \& Wangchuk (2007). Khanal et al. (2013) collected two specimens from central Nepal between 1850-1880 m.

\section{Himalayan Spotted Flat Celaenorrhinus munda}

\section{Moore (Image 12)}

Two individuals recorded near Bunakha, amongst which one was photographed basking in sunlight on leaves on a hillside on 14 May 2009 along the highway near Tanalium check post. Reported as 'rare' from Murree (Pakistan) to Sikkim and Shan States (Myanmar) by Evans (1932). Captain F.M. Bailey recorded it in central Nepal in May (Smith 1989, 2006). Not reported earlier from Bhutan.

Observations made in this study indicate that the moist temperate forests in western Bhutan is home to a number of rare and perhaps threatened species that are restricted to the eastern Himalaya, northeastern India and Myanmar. Further studies are needed to unveil the rich butterfly diversity existing in these little known forests.

\section{REFERENCES}

Evans, W.H. (1932). The Identification of Indian Butterflies-2nd Edition. Bombay Natural History Society, Bombay, 454pp.

Gogoi, M.J. (2012). Butterflies (Lepidoptera) of Dibang Valley, Mishmi Hills, Arunachal Pradesh, India. Journal of Threatened Taxa 4(12): 3137-3160; http://dx.doi.org/10.11609/JoTT.02975.3137-60

Haribal, M. (1992). Butterflies of Sikkim Himalaya and their Natural History. Sikkim Nature Conservation Foundation, Gangtok, Sikkim, India, 217pp.

Kehimkar, I. (2008). The Book of Indian Butterflies. BNHS, Oxford University. Delhi Press, 497pp.

Khanal, B., M.K. Chalise \& G.S. Solanki (2013). Threatened butterflies of central Nepal. Journal of Threatened Taxa 5(11): 4612-4615; http://dx.doi.org/10.11609/JoTT.02825.4612-5

Singh, A.P. \& R. Pandey (2004). A model for estimating butterfly species richness of areas across the Indian Sub-Continent: species proportion of family papilionidae as an indicator. Journal Bombay Natural History Society 101(1):79-89.

Singh, A.P. (2012). Lowland forest butterflies of the Sankosh River catchment, Bhutan. Journal of Threatened Taxa 4(12): 3085-3102; http://dx.doi.org/10.11609/JoTT.o2625.3085-102

Singh, I.J. \& M. Chib (2014). A preliminary checklist of butterflies (Lepidoptera: Rhophalocera) of Mendrelgang, Tsirang District, Bhutan. Journal of Threatened Taxa 6(5): 5755-5768; http://dx.doi. org/10.11609/JoTT.o3675.5755-68

Smith, C. (1989). Butterflies of Nepal (Central Himalaya). Tecpress Service L.P., Bangkok, 352pp.

Smith, C. (2006). Illustrated Checklist of Nepal's Butterflies. Craftsman press, Bangkok, 129pp.

Tshering, N. (2015). An annotated checklist of Butterflies from Royal Manas National Park, Gelephu, Bhutan. Spring 5: 1-9.

Poel, P. van der \& T. Wangchuk (2007). Butterflies of Bhutan. Mountains, hills and valleys between 800 and $3000 m$. Royal Society for Protection of Nature (RSPN), Thimphu, Bhutan, 71pp.

Wangdi, S., K. Wangdi, Sherub, R. Wangdi, S. Drukpa, M. Harada, T. Aoki, S. Yamagchi, M. Saito, Y. Igarashi, Y. Watanabe \& M. Yago (2012). Butterflies of Trashiyangtse Valley, eastern Bhutan (Part 1). The Butterfly Society of Japan (Teinopalpus) 62: 16-28.

Wangdi K. \& R. Shrub (2012a). Nature Guide Series. Nymphalids, Brush-footed Butterflies of Bhutan. Ugyen Wangchuk Institute for Conservation and Environment, Bumthang, Bhutan,77pp.

Wangdi,K. \& R. Shrub (2012b). Field Guide for Swallowtails of Bhutan. Ugyen Wangchuk Institute for Conservation and Environment, Bumthang, Bhutan, 130pp.

Wangdi, S., K. Wangdi, Sherub, R. Wangdi, S. Drukpa, M. Harada, T. Aoki, S. Yamagchi, M. Saito, Y. Igarashi, Y. Watanabe \& M. Yago (2013). Butterflies of Trashiyangtse Valley, eastern Bhutan (Part 2). The Butterfly Society of Japan (Teinopalpus) 64: 4-15.

Wynter-Blyth, M.A. (1957). Butterflies of the Indian Region. Bombay Natural History Society, Bombay, 523pp. 
Appendix 1. Butterflies recorded in moist temperate forests of Bhutan (Dochula Pass and Bunakha)

\begin{tabular}{|c|c|c|c|}
\hline & Family /Species & $\begin{array}{l}\text { Month of } \\
\text { record }\end{array}$ & Sites \\
\hline A. & Papilionidae & & \\
\hline 1 & $\begin{array}{l}\text { Common Windmill Atrophaneura } \\
\text { polyeuctes (Doubleday) }\end{array}$ & May & Bunakha \\
\hline 2 & $\begin{array}{l}\text { Rose Windmill Atrophaneura latreillei } \\
\text { (Donovan) }\end{array}$ & May & Bunakha \\
\hline 3 & $\begin{array}{l}\text { Tailed Redbreast Papilio bootes } \\
\text { Westwood }\end{array}$ & May & Bunakha \\
\hline 4 & Tawny Mime Chiasa agestor (Gray)* & May & Bunakha \\
\hline 5 & $\begin{array}{l}\text { Blue Peacock Papilio arcturus } \\
\text { Westwood }\end{array}$ & May & Bunakha \\
\hline 6 & $\begin{array}{l}\text { Glassy Blue Bottle Graphium } \\
\text { cloanthus Westwood }\end{array}$ & May & Bunakha \\
\hline 7. & $\begin{array}{l}\text { Bhutan Glory Bhutanitis lidderdalei } \\
\text { Atkinson }\end{array}$ & Sept. & Bunakha \\
\hline B. & Pieridae & & \\
\hline 8 & $\begin{array}{l}\text { One spot Grass Yellow Eurema } \\
\text { brigitta (Cramer) }\end{array}$ & Sept & Bunakha \\
\hline 9 & $\begin{array}{l}\text { Common Brimstone Gonepteryx } \\
\text { rhamni (Linnaeus) }\end{array}$ & May & Bunakha \\
\hline 10 & $\begin{array}{l}\text { Indian Cabbage White Pieris canidia } \\
\text { (Sparrman) }\end{array}$ & Sept & Bunakha \\
\hline 11 & $\begin{array}{l}\text { Large Cabbage White Pieris brassicae } \\
\text { (Linnaeus) }\end{array}$ & May & Bunakha \\
\hline 12 & $\begin{array}{l}\text { Hill Jezebel Delias belladonna } \\
\text { (Fabricius) }\end{array}$ & April Sept & Bunakha \\
\hline 13 & $\begin{array}{l}\text { Dark Jezebel Delias berinda } \\
\text { berinda Moore }\end{array}$ & July & Bunakha \\
\hline 14 & Spot Puffin Appais lalage (Doubleday) & May & Bunakha \\
\hline 15 & $\begin{array}{l}\text { Dark Clouded Yellow Colias } \\
\text { fieldii Ménétriés }\end{array}$ & May & Bunakha \\
\hline 16 & Colias sp. & May & Bunakha \\
\hline c. & Lycaenidae & & \\
\hline 17 & $\begin{array}{l}\text { Straightwing Blue Orthomiella } \\
\text { pontispontis Elwes* }\end{array}$ & May & Bunakha \\
\hline 18 & $\begin{array}{l}\text { Silver Forget-me-not Catochysops } \\
\text { panormus (C \& R. Felder) }\end{array}$ & May & Bunakha \\
\hline 19 & $\begin{array}{l}\text { Bhutya Lineblue Prosotas bhutia } \\
\text { (DeNiceville) }\end{array}$ & May & Bunakha \\
\hline 20 & $\begin{array}{l}\text { Plain Hedge Blue Celastrina } \\
\text { lavendularis (Moore) }\end{array}$ & May & Bunakha \\
\hline 22 & $\begin{array}{l}\text { Large Hedge Blue Celastrina huegelii } \\
\text { Moore }\end{array}$ & Sept & Bunakha \\
\hline 23 & $\begin{array}{l}\text { Hill Hedge blue Celastrina argiolus } \\
\text { (Linnaeus) }\end{array}$ & July & Bunakha \\
\hline 24 & $\begin{array}{l}\text { Pale Hedge Blue Udara dilecta } \\
\text { (Moore) }\end{array}$ & July & Bunakha \\
\hline 25 & $\begin{array}{l}\text { Tailless Bushblue Arhopala ganesha } \\
\text { (Moore) }\end{array}$ & April & Bunakha \\
\hline 26 & $\begin{array}{l}\text { Purple Sapphire Heliophorus epicles } \\
\text { Godart }\end{array}$ & Sept & Bunakha \\
\hline 27 & $\begin{array}{l}\text { Golden Sapphire Heliophorus brahma } \\
\text { Moore }\end{array}$ & July & Dochula \\
\hline 28 & $\begin{array}{l}\text { Green Sapphire Heliophrous } \\
\text { androcles Doubleday \& Hewitson }\end{array}$ & July & Dochula \\
\hline 29 & $\begin{array}{l}\text { Dull Green Hairstreak Esakiozephyrus } \\
\text { icana Moore* }\end{array}$ & July & Dochula \\
\hline 30 & Slate Royal Maneca bhotea Moore* & July & Dochula \\
\hline 31 & Common Flash Rapala nissa (Kollar) & May & Bunakha \\
\hline 32 & $\begin{array}{l}\text { Mixed Punch Dodona ouida } \\
\text { (Hewtison) }\end{array}$ & April-May & Bunakha \\
\hline
\end{tabular}

\begin{tabular}{|c|c|c|c|}
\hline 33 & $\begin{array}{l}\text { Common Punch Dodona durga } \\
\text { (Kollar) }\end{array}$ & May & Bunakha \\
\hline 34 & $\begin{array}{l}\text { Striped Punch Dodona adonira } \\
\text { Hewitson }\end{array}$ & May & Bunakha \\
\hline 35 & $\begin{array}{l}\text { Tailed Judy Abisara neophron } \\
\text { (Hewitson) }\end{array}$ & Sept & Bunakha \\
\hline D. & Nymphalidae & & \\
\hline 36 & $\begin{array}{l}\text { Yellow Woodbrown Lethe nicetas } \\
\text { Hewitson* }\end{array}$ & July & Dochula \\
\hline 37 & $\begin{array}{l}\text { Common Woodbrown Lethe sidonis } \\
\text { (Hewitson) }\end{array}$ & July Sept & Bunakha \\
\hline 38 & $\begin{array}{l}\text { Long-brand Bushbrown Mycalesis } \\
\text { visala Moore }\end{array}$ & July & Bunakha \\
\hline 39 & $\begin{array}{l}\text { Chumbi Wall Chonala masoni } \\
\text { (Elwes)* }\end{array}$ & July & Dochula \\
\hline 40 & $\begin{array}{l}\text { Veined Labyrinth Neope pulaha } \\
\text { (Moore) }\end{array}$ & April July & Bunakha \\
\hline 41 & $\begin{array}{l}\text { Scarce Labyrinth Neope pulahina } \\
\text { Evans* }\end{array}$ & July & Dochula \\
\hline 42 & $\begin{array}{l}\text { Small Silverfork Zophoessa jalaurida } \\
\text { elwesi Moore* }\end{array}$ & July & Dochula \\
\hline 43 & Pallid Argus Callerebia scanda (Kollar) & Sept & Bunakha \\
\hline 44 & $\begin{array}{l}\text { Himalayan Fivering Ypthima sakra } \\
\text { Moore }\end{array}$ & Sept & Bunakha \\
\hline 45 & $\begin{array}{l}\text { Chocolate Pansy Junonia iphita } \\
\text { (Cramer) }\end{array}$ & Sept & Bunakha \\
\hline 46 & Blue Pansy Junonia orithiya (Linnaeus) & July & Dochula \\
\hline 47 & Chestnut Tiger Parantica sita (Kollar) & Sept & Bunakha \\
\hline 48 & Red Lacewing Cethosia biblis (Drury) & May Sept & Bunakha \\
\hline 49 & $\begin{array}{l}\text { Grand Duchess Euthalia patala } \\
\text { (Kollar) }\end{array}$ & Sept & Bunakha \\
\hline 50 & $\begin{array}{l}\text { Common Tortoise Shell Aglais } \\
\text { cashmiriensis (Kollar) }\end{array}$ & May & Bunakha \\
\hline 51 & $\begin{array}{l}\text { Chocolate Tiger Parantica melaneus } \\
\text { (Cramer) }\end{array}$ & May & Bunakha \\
\hline 52 & $\begin{array}{l}\text { Painted Lady Vanessa cardui } \\
\text { (Linnaeus) }\end{array}$ & May & Bunakha \\
\hline 53 & $\begin{array}{l}\text { Indian Red Admiral Vanessa indica } \\
\text { (Herbst) }\end{array}$ & April May & Bunakha \\
\hline 54 & $\begin{array}{l}\text { Queen of Spain Fritillary Issoria } \\
\text { lathonia (Linnaeus) }\end{array}$ & May & Bunakha \\
\hline 55 & Sullied Sailer Neptis soma Moore & Sept & Bunakha \\
\hline 56 & $\begin{array}{l}\text { Pale Hockeystick Sailer Neptis manasa } \\
\text { Moore* }\end{array}$ & May & Bunakha \\
\hline 57 & $\begin{array}{l}\text { Himalayan Sergeant Athyma } \\
\text { orientalies Elwes }\end{array}$ & May Sept & Bunakha \\
\hline 58 & $\begin{array}{l}\text { White Commodore Parasarpa dudu } \\
\text { (Doubleday)* }\end{array}$ & May & Bunakha \\
\hline 59 & Yellow Coster Acraea issoria (Hubner) & May & Bunakha \\
\hline 60 & Circe Hestina nama (Doubleday) & Sept & Bunakha \\
\hline F. & Hesperiidae & & \\
\hline 61 & $\begin{array}{l}\text { Spotted Demon Notocrypta } \\
\text { feisthameli (Boisduval) }\end{array}$ & May & Bunakha \\
\hline 62 & $\begin{array}{l}\text { Brown Bush Bob Pedesta panditade } \\
\text { Nicéville }\end{array}$ & May & Bunakha \\
\hline 63 & $\begin{array}{l}\text { Chequered Ace Solvia lucasii separata } \\
\text { Moore }\end{array}$ & July & Bunakha \\
\hline 64 & $\begin{array}{l}\text { Contiguous Swift Polytremis lubricans } \\
\text { lubricans Herrich-Schäffer }\end{array}$ & Sept & Bunakha \\
\hline 65 & $\begin{array}{l}\text { Himalayan Spotted Flat } \\
\text { Celaenorrhinus munda Moore* }\end{array}$ & May & Bunakha \\
\hline
\end{tabular}

